University for Business and Technology in Kosovo

UBT Knowledge Center

UBT International Conference

2016 UBT International Conference

Oct 28th, 9:00 AM - Oct 30th, 5:00 PM

\title{
Online journalism, ethics and challenges
}

Musa Sabedini

University for Business and Technology, musa.sabedini@ubt-uni.net

Follow this and additional works at: https://knowledgecenter.ubt-uni.net/conference

Part of the Social and Behavioral Sciences Commons

\section{Recommended Citation}

Sabedini, Musa, "Online journalism, ethics and challenges" (2016). UBT International Conference. 37. https://knowledgecenter.ubt-uni.net/conference/2016/all-events/37

This Event is brought to you for free and open access by the Publication and Journals at UBT Knowledge Center. It has been accepted for inclusion in UBT International Conference by an authorized administrator of UBT Knowledge Center. For more information, please contact knowledge.center@ubt-uni.net. 
Book of Proceedings

International Conference on Social Sciences, Humanities, and other sciences

\title{
Online journalism, ethics and challenges"
}

\author{
Musa Sabedini \\ UBT - Higher Education Institution, Lagjja Kalabria, 10000 p.n., \\ Prishtine, Kosovo \\ msua.sabedini@ubt-uni.net
}

\begin{abstract}
Expansion of Internet and creation of online media have offered more opportunities for freedom of expression, civil journalism and democracy in general, however, the extended freedom has raised new concerns, related to ethics above all, where the most pressing are associated to hate speech, inaccuracy of information, inappropriate language in online media, etc.

Whatsoever, it must be emphasized that evolution of technology is not the main and only factor generating problematic issues related to ethics, especially in online media. There are other factors, too. Bearing in mind that content of online media is created by a whole variety of categories of individuals - not necessarily journalists - consequently raises dilemmas about professional ethics which, as mentioned above, are intensely expressed in online media.

Such an element and consistent concerns related to reporting, journalism standards in online media and professional ethics were the main reasons to focus on this topic, which addresses the dilemma on whether we need to create new reporting standards for online journalism.
\end{abstract}

\section{Bad online journalism and its users}

Umberto Eco, not coincidentally has said that, Internet has given the right of word to the fools. "Social media gives legions of idiots the right to speak", are the words of Umberto Eco, who chose that way to attack the internet.

The structure of internet, according to Eco, favors the spread of those who propagate nonsense words. At this point, according to him, the role of newspapers is very important because "along with teams of experts, they must filter information coming from the internet because today, none of us is able to understand if an information is reliable, or not". To do that, according to him, "newspapers should dedicate at least two pages to analysis and criticism on online sites, just as teachers have to teach the students how to use the data to build a case".

\subsection{The language used in online media is denigrating good journalism}

Despite the internet, social media and portals have made a revolution in placing of the breaking news, it does not mean that everything is fine with this speed of informing. 
Book of Proceedings

International Conference on Social Sciences, Humanities, and other sciences

Online media has caused a revolution in Kosovo and still are making a step forward to be closer to readers and viewers. Personally, I think that the fact that everyone has the right to open a portal and without any code or any other professional criterion, puts in doubt their own reliability.

If we see portals, you can notice in the start that, there dominate the news, written and taken on facebook. There are well-known personalities, deputies and other categories that are present almost nonstop on online media.

One thing to worry about on social media, it remains the language used in them. Maybe even here, Umberto Eco has had a plight.

Inappropriate language denigrates good journalism. From this unrestrained language, mostly benefit "the fools", as Eco said. Articles made by this category, belong to second level, therefor in a normal society they should be corrected and selected, before taking the green light of publication.

It is created the impression that if a person owns a facebook account, it is also a media and a journalist. This is the biggest risk of online journalism. Social media should be used only as a starting point or a possible source, but never to create serious daily news from them.

Online journalism should avoid this category of users, who know how to insult and how to give different labels. The vocabulary used by this category, such as on social networks, as well as in various portals, is extremely low. Even worse, these insults are supported by certain categories of users.

Few professional journalists, who work in portals, understand very well my concern, while there are those who don't want to understand it because this kind of journalism fits with their way of living.

Fortunately, the few daily newspapers have opened their portals and it is a hope that others can learn how to write articles. Newspapers, however differ in this aspect because they have less chance of error.

I don't want to talk about ethics and its respect because there is a mountain of errors and abuses by all parties. Serious portals are often criticized for not giving space to others to comment or give their opinions. This reduction or small selection that is happening in journalism, for me is very positive. We have a responsibility to sincere readers because we shouldn't serve them news, where beneficiaries are criminal underworld groups. Most commentators on social networks are associated with certain criminal group and whenever they want to devalue the journalism, they overflow with demeaning comments to those media.

Advantages, such as speed in the transmission of information, reduce of costs, but also the loss of ongoing audience to new media, has forced traditional media to accept the new reality and try to adapt to the new era, which started in our country.

\section{The loss of exclusivity}

With the emergence of online media, exclusivity of the news has opened a debate among traditional journalists and those who defend the new media. Experts have different opinions about this, but despite thoughts that protect the parties, one thing is certain: "De facto" there is no exclisivity anymore and already many things have changed. 
Newspapers and Internet

If until recently, receiving a statement, interview or pronouncement from a politician somehow it was an impossible mission for the new media, but also for the media not close to them (politicians), today we can say that all of them have equal access to such information.

If earlier, the prime minister or opposition's leader would have given an interview, there were great chances for 2-3 mainstream media. All others, dozens of TV stations, newspapers, portals, radios etc., later were forced to take the interview or statement from the media that did the interview. Even when the statement was given for all media, most of the new media, but also small traditional media, failed to follow the statement, through their journalists who were present at the conference.

\subsection{Advantages of online journalism}

The speed of placing news, the immediate opportunity to supplement, to correct or remove unsupported news are the main reasons why online journalism is spreading everywhere with such a dizzying speed.

This effect is observed in increasing the number of advertisements and other commercial publications in portals, enabling independence of their own editorial policy.

Online journalism has some crucial advantages over traditional journalism: there are less costs, for the publisher, but also for the reader; it takes less time to read things the reader wants to read; it can be updated during 24 hours, then every hour, news can be updated with new data.

An important advantage of online journalism is the possibility of processing and constant updating of news. In this way, first, journalist can publish a version with less information and then depending on the information coming, the same news can be updated and enriched.

With it, journalists can achieve some goals. First, journalist wins time, so it publishes news very quickly, meanwhile, the reader gets the basic information about an event. With further updating, the portal manages to retain the reader associated with the event, while the reader constantly gets more informed in real time. This way, the portal increases the audience, but also informs the reader very quickly.

Another advantage of online journalism is the elimination of the control mechanisms, which the news must pass, until it is published in a newspaper or television. These links control, in many cases serve as filters of censorship of news.

In online media, organizational structure eliminates some link of this kind, making the publication of news, a simpler and shorter process. This also reduces the possibility of controlling and censoring the news.

\section{Is the future of online journalism safe?}

Despite the problems faced by the new media, its future is promising. Problems with the funding of portals (whose income depends 100 per cent from advertising), it seems that with time, the problem will be solved, with an increasing number of companies that advertise on the internet, and this, except 
that portals will provide a more secure future, it will significantly affect the increase in the quality of these media, increasing competitiveness with traditional media, which is losing the battle in every day.

The increased number of Internet users, use of the internet as a primary tool for informing the younger generations and the switch on the internet of a huge part of utility of companies and state institutions, opens the way to further increase of portals and informative newspapers.

\subsection{Disadvantages of online media}

Pornography and sexual materials, mental problems, problems with addiction, mental disorders, social problems, frightening photographs of killed or hurt people, hate, drugs, guns and violence, incorrect and irrelevant data, there is no limitation, regarding of content and personal informations that can be declared by children, while using programs for communication or social networking sites.

There are hackers and viruses, improper functioning of the system, data loss, damage and destruction of entire hardware components, there are legal and financial risks, illegal use of protected content, the possibility of abusing with financial transactions etc.

\section{Who is part of online journalism?}

Digital journalism, known as online journalism, presents contemporary form of journalism in which editorial content is distributed via the Internet. What online journalism features, is a question which is being debated by researchers, and besides, it can be said that the primary product of journalism, of news and reports on current affairs, is presented as a form of an alone content, or in combination with text, audio, video and other interactive format, distributed on digital media platforms. There is no absolute compliance about what is meant by online and digital journalism.

Finally, we should summarize by saying that online media and technological developments, are changing not only the media, but also the way we think media.

In the past, the media were powerful elite institutions, which were the only ones which had the power to build and control public opinion, or to decide which information actually is news, and which not. Today, ordinary people are those who can gather information, distribute and comment. This way, the public can influence the media, showing what the news is. And this is just the beginning, because the future can't be imagined.

Social media and portals in Kosovo are already an integral part of public communication and the development of journalism. Undoubtedly, technology has an impact on quality and ethics in practical terms of doing journalism.

Debate for portals in Kosovo, mainly is taking place in two areas: from the perspective of consumers of news and from the perspective of analyzing the quality of news, placed on these media. Lack of analysis of the news production and lack of context analysis of the establishment and operation of this type of media, leaves this debate uncompleted and unfinished. 


\subsection{Privacy remains a challenge, placement and quality of news}

The main challenge still remains the privacy and quality of news. For the first half, Kosovo's institutions should do more to create the necessary legal infrastructure and regulation of the market, while for the second part, the market regulates itself, within itself.

\subsection{Cyber-attacks and quotations, next challenge}

Another challenge for online journalist remains the quotation by portals, for published - borrowed articles. There are many portals that use copy-paste method, which represents a major devaluation of the presented news, even worse when the borrowed news is not cited.

Meanwhile, cyber-attacks remain the main problem of the future of online journalism.

Somehow, serious portals have some security in their servers, but it can be lost within the twinkling of an eye.

In Kosovo, there are no responsible people, who deal exclusively with cyber interventions, with numerous hackers. This makes even more difficult the operation of online media.

\subsection{Instructions for online journalism}

These guidelines for online journalism are an integral part of the guidelines of the Media Code (Kodit të Medieve), whose principles are applied to online journalism. And these guidelines, deal with the contents of comments and written responses from the public, which are posted on media sites and news agencies, based on the internet.

Guide to the Press Code of Kosovo Pristina, March 2015

\section{Content:}

1. Hate speech and discrimination

2. Crime Reporting

3. Protection of children and minors

4. The right to privacy

5. Copyright

6. Protection of Sources

7. The right to reply

8. The difference between information and advertising content

\section{The Press Code of Kosovo}

This code, which derived from existing international standards of practice of journalism, aims to serve as a basis for self-regulatory system, which would be considered professionally and morally obligatory for journalists, reporters, editors, owners and publishers of newspapers, portals and news agencies. 
Book of Proceedings

International Conference on Social Sciences, Humanities, and other sciences

\subsection{Ethics in online journalism}

Ethical principles, which must be applied in online journalism, such as unbiased information, verification of the news, quotation of sources, loan of photos and videos etc., are a matter of concern for many agencies, portals and various existing websites.

Unfortunately, portals are the biggest violators of ethics, without ignoring newspapers. Some concrete examples, that we will treat shows how far the portal ethics has gone, causing damage to citizens.

The ethics in online journalism and ethical behavior on websites today is a subject that arouses continued debate and discussion, not only for ethical standards that are applied, but generally about the future of journalism in the era of digitalization and journalism website.

Ethically, in digital journalism, respectively, online journalism - web journalism, many problems have been emerged. In online media, today journalists make mistakes that media people should not be doing: e.g. not publishing biased and unverified information, from people, who are able to pay large amounts of money for their publications. This undermines the integrity of independent journalism and transforms journalism into a conflict of interest.

There are many portals today that do so, contrary to professional ethics and standards of professional journalism. Other cases, when the ethics of online media is violated, is the call and use of anonymous sources, then copying of materials in copy - paste style from other portals, without verifying their accuracy. Other action which violates ethics, is the invention of resources, the compilation of news with sensational headlines that distort the reality.

Another risk in online journalism and journalism in general, is the falsification of reality, especially through photography. "This risk exists in our days and will constantly be present if media editors and online editors are not careful" (John Pavelik from his book: Ethical requirements in digital journalism, 2009).

\subsection{Damages and legal violations of journalistic reporting}

Legal damages that may arise from journalistic reporting, are mainly from court reporting; reporting for serious crimes, disasters, accidents, fires, murders, rape, prostitution, smuggling, corruption etc.

Usually, legal damages in reporting situations come mainly about defamation. The definition of defamation is the publication of a paper, which damages the reputation of a person or organization.

\subsection{Social media, new weapon in the hands of "the good" and "the bad"}

Social media today have become one of the most powerful tools of communication in the world. Even Kosovo, no matter that here is involved with a delay, is estimated that it entered strongly, considering the number of users of media and social networks. The fast involvement of Kosovo in these media has followed the rapid development of the internet. 
Newspapers and Internet

Social media today is considered as a powerful tool for communication, promotion, diffusion of ideas, platforms and messages, whether commercial or political. In some cases, mastery of the use of these media is considered a key factor in electoral contests in various countries worldwide.

Valon Canhasi, a local expert of social networks, says that the number of users of social media in Kosovo is very large. According to him, about 70 percent of population participates in these media, spending up nearly three hours a day in their use.

"This format, this type of communication, gives you the opportunity to promote your idea, your own cause, to find supporters to your cause in a matter of minutes, in real time, because many people, approximately 500 thousand people, use Facebook every month and spend an average of three hours on this platform. The beauty of all this, is that it is transparent, and the public has the opportunity to communicate to anyone, you can communicate directly with the responsible person," says Canhasi.

"Social media has a major role, is a very powerful and effective tool, and has a very low cost of transmission of the message, as an example. But we have to keep our skepticism regarding to the transmission of those messages, as long as, the transmitted message is biased, it doesn't have the proper criticism, and it doesn't have another opinion. But it allows a much easier communication with citizens," estimates Dardan Qadraku, from PAKT organization.

"There are organizations which call out for carrying terrorist acts. This practice unfortunately has begun to affect our country. There are several organizations that use the internet and the social media in general, to promote these events, the promotion of various messages, focusing at the young people, is a fact that has led to the involvement of Kosovar youth in different wars," says Qadraku.

\subsection{The truth does not matter - how are people affected by negative news}

Negative news for terror, are reached unfiltered and directly through social media. Professor Oliver Quiring, communication scientist, says that people are almost flooded by negative news. "There is always a pressure to produce something new, even on the media. Something that before was expressed in meetings in the clubs or pubs, now is expressed in public not only in words, but also as a text. Here, perhaps we should pay more attention to whether the news comes from serious and consolidated sources." (Oliver Quiring is Professor of Social Sciences and Communication at the University of Mainz. He studies the changing of media, news in the media and political communication).

\subsection{How are used online media and social networks, and by whom?}

Kosovo is already crowded with portals, it is crowded with news of various natures. It has changed fundamentally the way of doing journalism and being a factor with only a daily topic.

But who are the ones who put us in various trials and why the reader - healthy public must be careful and preserved from "uncontrolled" and "perverse" news.

While I was doing some analysis of our portals, I noticed a headline in Gazeta Express: "Predicts Vali Corleone: Here's when visas will be removed for Kosovars" (Wednesday, October 19, 2016)

At first sight, inattentive reader falls victim of this title. Who is Vali Corleone that is talking about visas. What is his weight, even if it is published in the section "Magazina". 
Book of Proceedings

International Conference on Social Sciences, Humanities, and other sciences

Original quotation: "Vali Corleone has just made a great promise for all Kosovars, who will travel abroad without a visa. He, in a recent Facebook post said that on the occasion of his birthday, June 30, 2017, all Albanians / Kosovars will have the opportunity to travel to Europe without visas ".

In fact, portals since long time ago are mentioning and spreading words of Vali Corleone, due to power of his money rather than knowledge. Corleone has forgotten that he has a trial and an indictment for causing general danger, but that online media don't mention.

The other case concerns Veton Surroi. In fact, it isn't the first time that Veton Surroi falls victim of portals. On October 8, 2016, Veton Surroi in a column in Koha Ditore wrote: "The level of professional laziness, which is produced by "new media" or "Low professional level of media close to the authorities, makes folly the best conductor of the information to its monstrous distortion ".

Surroi's text Continues: Last Sunday I gave an interview for "Koha Ditore", in the thematic number for political consensus in Kosovo, respectively its lack. Three days later, in a part of public opinion, was the impression that in that interview I stated that: KLA was a criminal force that wanted to kill dr. Rugova and LDK; 200 thousand voters of PDK are criminals.

Of course, I didn't say any of these things in the interview, but already there is a number of people who believe deeply that I said so.

How it is possible the traveling of information into becoming its opposite?

Surroi further strengthens the conviction: "There are few people among us, from whom you can hear that they "read on Facebook" or have "read on the Internet." Thirty years earlier, the same people would say that they "have heard it on the radio or TV", without attributing exactly in which radio or program, and whose words are? Unlike thirty years ago, the ability of the distribution of "what you read on Facebook" is incomparably greater and worse, "said Surroi.

The other extreme of our portals exceeded professional and ethical limits, by placing hundreds of news for Shyhrete Behluli's son's wedding. Everything was given in the positive boom but not a single line was written nor said about the cost of that fabulous wedding and, is there any unpaid tax from her and so on.

I want to mention some titles:

"Bëri bujë të madhe martesa e djalit të Shyhretes", Gazetaexpress, e diel, 02 Tetor 2016.

"Mire se erdhe o Yll, na e zdrite shtëpinë", "Kosova Sot Online", tetor 2016.

"Sa kushtoi dasma që Shyhretja ia bëri djalit të saj”, Gazetaexpress, e diel, 02 tetor 2016.

"Pamje nga martesa e djalit të Shyhrete Behlulit: me foto, Gazetaexpress, e shtune, 01 tetor 2016.

"A ka qenë mbrëmë Shkurte Fejza në dasmën e djalit të Shyhretes", Gazetaexpress, e shtune, 01 tetor 2016.

"Ja si u duk nusja e Shyhrete Behlulit dje në ditën e martesës", Gazetaexpress, e shtune, 01 Tetor 2016

"Mikpritjen e Shyhretës si vjehërr do e ëndërronte secila nuse", Gazetaexpress, e shtune, 01 tetor 2016. "Gjithçka gati tek familja Behluli për të marrë nusen, ja me sa makina do e marrin", Gazetaexpress, e premte, 30 shtator 2016. 
Newspapers and Internet

The case of injury and the clash between rappers Noizy and Cosman, of course, is part of ethical violations and incomplete reports of portals. These two rival groups have an arrogant behavior in their genesis, the use of the criminal dictionary in their songs should be part of professional of journalists, who are prepared for such cases. Kosovo public was "shocked" with the great passion of portals to know every detail of the cold "war" between the two rival groups.

\section{Thank You!}

\section{Consulted literature:}

1. Diskutim për Etikën

2. Etika e gazetarisë dhe sfidat

3. Udhëzues për gazetarë për qasje në dokumente publike

4. Etika e gazetarisë - autor kroat

5. Elementet e gazetarisë- Bill Kovach, Tom Rosenstiel

6. Etika në media - Philip Patterson dhe Lee Wilkins

7. Instituti i Medias Tiranë

8. Manual për gazetarët- Si të mbijetojmë

9. Gazetari Universal- David Randall

10. Raportimi dhe shkrimi i lajmeve- Melvin Mencher

11. Udhëzues për Kodin e Medieve të Shkruara-KMSH

12. Format e gazetarisë kërkimore

13. Gazetaria 1

14. Gazetari universal

15. Gazetaria investigative: Mjetet ligjore dhe etike

16. Histori e gazetarisë

17. Çështje globale-Media dhe Etika 